\title{
Cross-cultural adaptation of the General Comfort Questionnaire to Brazilian patients with myocardial infarction
}

\author{
Adaptação transcultural do General Comfort Questionnaire para brasileiros com infarto do miocárdio \\ Adaptación transcultural del General Comfort Questionnaire para brasileños con infarto de miocardio
}

\author{
Joselice Almeida Góis', Kátia Santana Freitas", Katherine Kolcaba"', Fernanda Carneiro Mussi' \\ ' Universidade Federal da Bahia, School of Nursing. Salvador, Bahia, Brazil. \\ "Universidade Estadual de Feira de Santana. Feira de Santana, Bahia, Brazil. \\ III The University of Akron. Ohio, United States of America.
}

\begin{abstract}
How to cite this article:
Góis JA, Freitas KS, Kolcaba K, Mussi FC. Cross-cultural adaptation of the General Comfort

Questionnaire to Brazilian patients with myocardial infarction. Rev Bras Enferm [Internet]. 2018;71(6):2998-3005.

DOI: http://dx.doi.org/10.1590/0034-7167-2017-0557
\end{abstract}

Submission: 08-30-2017 Approval: 04-26-2018

\begin{abstract}
Objective: Describe the first stages of the cross-cultural adaptation process of the General Comfort Questionnaire for myocardial infarction patients in intensive care units. Method: This is a study of qualitative and quantitative research and analysis techniques. Conceptual, item, semantic and operational equivalence was performed. Fifteen items were added to the original instrument to better represent the comfort experienced by myocardial infarction patients in intensive care units. The content validity index was applied to analyze the answers of the experts; it was considered adequate above 0.78. Results: Some changes suggested by the experts for better understanding were adopted. All items were kept, obtaining a scale of sixty-three items. In the pre-test conducted with 30 subjects, the instrument was considered adequate to the target audience. Conclusion: The adapted version of the General Comfort Questionnaire for people with myocardial infarction is adequate to the target audience.
\end{abstract}

Descriptors: Cross-Cultural Comparison; Comfort Care; Myocardial Infarction; Validation Studies; Questionnaires.

\section{RESUMO}

Objetivo: Descrever as etapas iniciais do processo de adaptação transcultural do General Comfort Questionnaire para pessoas com infarto do miocárdio internadas em terapia intensiva. Método: Estudo cujas técnicas de investigação e análise foram de natureza qualitativa e quantitativa. Realizou-se a equivalência conceitual, de itens, semântica e operacional. Quinze itens foram acrescentados ao instrumento original para retratar melhor o conforto experienciado por pessoas com infarto em terapia intensiva. Aplicou-se o índice de validade de conteúdo para análise das respostas dos especialistas, sendo considerado adequado acima de 0,78. Resultados: Algumas alterações foram sugeridas pelos especialistas para melhor compreensão, as quais foram adotadas. Todos os itens foram mantidos, obtendo-se uma escala com 63 itens. No pré-teste, realizado com 30 sujeitos, constatou-se a adequação do instrumento ao público - alvo. Conclusão: O General Comfort Questionnaire para pessoas com infarto do miocárdio configura-se como uma versão propícia a aplicação ao público alvo.

Descritores: Comparação Transcultural; Cuidados de Conforto; Infarto do Miocárdio; Estudos de Validação; Questionários.

\section{RESUMEN}

Objetivo: Describir las etapas iniciales del proceso de adaptación transcultural del General Comfort Questionnaire para personas con infarto de miocardio internadas en terapia intensiva. Método: Estudio cuyas técnicas de investigación y análisis fueron de naturaleza cualitativa y cuantitativa. Se realizó la equivalencia conceptual, de ítems, semántica y operacional. Quince elementos fueron añadidos al instrumento original para retratar mejor el confort experimentado por personas con infarto en terapia intensiva. Se aplicó el índice de validez de contenido para análisis de las respuestas de los especialistas y fue considerado adecuado por encima de 0,78. Resultados: Algunas alteraciones fueron sugeridas por los expertos para una mejor comprensión, las cuales fueron adoptadas. Todos los ítems fueron mantenidos, obteniéndose una escala con sesenta y tres ítems. En el pre- 
test, realizado con 30 sujetos, se constató la adecuación del instrumento al público objetivo. Conclusión: El General Comfort Questionnaire para personas con infarto de miocardio es una versión propicia para la aplicación al público objetivo.

Descriptores: Comparación Transcultural, Cuidados de Confort, Infarto de Miocardio, Estudios de Validación, Cuestionarios

\section{CORRESPONDING AUTHOR Joselice Almeida Góis E-mail: joselice.gois@hotmail.com}

\section{INTRODUCTION}

Acute myocardial infarction (AMI) is the major cause of mortality in Brazil (DATASUS, 2014). Hospital mortality caused by this disease remains high, reaching $16.2 \%$ in 2005 and $15.3 \%$ in 2010, considering hospitalization across the country ${ }^{(1)}$.

This sudden event requires hospitalization in an intensive care unit (ICU) due to its life-threatening character. MI patients are submitted to diagnostic and therapeutic procedures, continuous monitoring and specific medication. In addition, they experience one of the most complex and mechanized treatment scenarios in the ICU as a result of the severity of hospitalized patients and the arsenal of equipment found in this setting ${ }^{(2)}$. The service in ICUs has been characterized mainly by the Cartesian/mechanistic logic, with the patient considered an ill body, in fragmented parts, where rationality overcomes subjectivity ${ }^{(3)}$. Hospitalization alone causes discomfort and distance from daily life, causing the patient to be far from social, family and work life ${ }^{(4)}$.

In this context, the health team should reflect and understand the situation experienced by the people in this condition and seek to offer care practices to promote comfort.

Comfort can be understood as a subjective multidimensional phenomenon that changes in time and space, resulting from the interaction of the individual with him/herself, the environment and with others, as a positive, relational experience that can happen even in adverse moments ${ }^{(5)}$. It is also understood as a state of well-being that occurs in any stage of the healthdisease process ${ }^{(6)}$. For Kolcaba ${ }^{(7)}$, comfort is positive, holistic, theoretically defined and operable.

Although the concept of comfort has been better understood recently, there is a lack of precise instruments that can measure it. These instruments include the General Comfort Questionnaire (GCQ), designed by Katherine Kolcaba, which was validated to measure comfort of people in general condition of illness.

No instrument has been identified to measure comfort of people with AMI in national and international databases, although this is a life-threatening cardiovascular event that causes discomforts worldwide. This gap in the literature justifies a cross-cultural adaptation of the GCQ to people with myocardial infarction in intensive care units in Brazil, who present social and cultural and illness characteristics that differ from those of the place where the GCQ was originally validated, requiring a cross-cultural adaptation. A critical and procedural evaluation is required to check for instrument ability to measure the event in a new reality ${ }^{(8)}$. "Cross-cultural adaptation" has been used to characterize a process that analyzes linguistic and cultural aspects to prepare one instrument to be used in another one ${ }^{(9)}$.

This study recognizes the importance of evaluating the level of comfort of AMI patients and guiding the adoption of care practices for comfort promotion and operationalization, allowing the creation of interventions based on empirical evidence.

\section{OBJECTIVE}

To describe the first stages of the cross-cultural adaptation process of the General Comfort Questionnaire for myocardial infarction patients in intensive care units.

\section{METHOD}

\section{Ethical aspects}

The study observed the requirements of Resolution 466/2012 for research involving human beings and was approved by the Research Ethics Committee of the Nursing School of Universidade Federal da Bahia-EE-UFBA. In addition, the author's authorization was obtained to use the original instrument. All 30 participants signed an informed consent form (ICF) in two counterparts.

\section{Theoretical and methodological reference}

The GCQ was developed by Dr. Katherine Kolcaba, a professor at the University of Akron, in Ohio, USA, to assess the comfort of people in general situation of illness and hospitalization. It has 48 items referring to states of comfort (calmness, relief and transcendence) and the contexts in which they are experienced (physical, psycho-spiritual, environmental and sociocultural contexts). The answers range from 1 (I totally disagree) to 4 (I totally agree). The higher the score, the higher the level of comfort, the lower the score, the lower the level of comfort and the greater the need for intervention.

The Universalist model proposed by Regnault \& Herdman ${ }^{(10)}$ and Reicheiheim \& Moraes $^{(8)}$ was used to conduct the crosscultural adaptation process, which considers the constructs may not be the same in different contexts and cultures. Therefore, the studied concept should be investigated in advance to see whether it already exists in the new culture and if it is interpreted accordingly, so that a cross-cultural equivalence can be established later. The literature recommends that, in a cross-cultural adaptation process, conceptual and item, semantic and operational equivalence should be evaluated ${ }^{(8,10)}$.

In this study, all these equivalences were evaluated using the sequence of several stages proposed by Guillemin, Bombardier \& Beaton ${ }^{(11)}$, Regnault \& Herdman ${ }^{(10)}$, Reicheinheim $\&$ Moraes $^{(8)}$, as illustrated in Figure 1. 


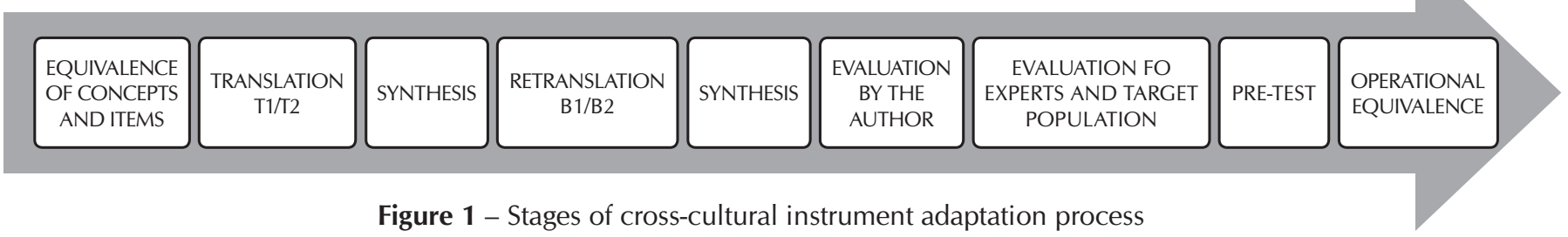

\section{Study type}

This is a cross-sectional study, which used theoretical and methodological procedures to validate content in the cultural adaptation process of the General Comfort Questionnaire (GCQ) to measure comfort of myocardial infarction patients in ICU. The study is in integral party of a master's thesis ${ }^{(12)}$.

\section{Inclusion criteria}

The inclusion criteria of the study involved: patients over 18 years of age, medical diagnosis of acute myocardial infarction confirmed through medical records, admission to intensive care unit, clinical conditions to participate in the study, informed consent form signed by the patient. Patients with non-preserved cognitive function were excluded from the study.

\section{Study population}

This study had 30 participants of both sexes, with medical diagnosis of myocardial infarction, hospitalized in the intensive care unit.

\section{Methodology procedures}

\section{Study site and period}

This study was conducted in intensive care units of two large institutions specialized in cardiology in the municipality of Feira de Santana, Bahia, between February 2015 and February 2016.

\section{Stages}

1st stage - Evaluation of conceptual and item equivalence

For a clear understanding and development of the construct map, a comprehensive literature review was conducted about comfort in the Brazilian context. In addition, the theory underlying the original instrument was studied, and the relationship between the GCQ items with their comfort states and contexts was analyzed. Considering the instrument adaptation to assess comfort of myocardial infarction patients in the ICU, the literature about the needs and experiences of these individuals was reviewed and analyzed to investigate whether the instrument items reflected the situation experienced in this illness condition. After that, the steps corresponding to the semantic equivalence were followed.

\section{2nd stage - GCQ translation into Brazilian Portuguese}

The General Comfort Questionnaire (GCQ) was translated into Brazilian Portuguese by two Brazilian translators qualified in the English language, who produced the first two versions of the GCQ (T1 and T2).

\section{3rd stage - Synthesis of translations}

$\mathrm{T} 1$ and $\mathrm{T} 2$ were synthesized by consensus among the researchers, using words and terms to make the items understandable by the target population.

\section{4th stage - Retranslation or back translation}

Subsequently, the synthesized version was retranslated by two English translators qualified in the Portuguese language, who produced two versions of the instrument (B1 and B2).

\section{5th stage - Resynthesis}

B1 and B2 in English were evaluated by another bilingual translator who formally analyzed the equivalence between the two retranslations and the original instrument. This evaluation was independent and blind in relation to translators and retranslators, as the translator responsible for the synthesis of $\mathrm{B} 1$ and $\mathrm{B} 2$ did not know which one was the original instrument and the retranslated version.

6th stage - Evaluation by the author of the original instrument

After that, the synthesis was evaluated by the author of the original instrument to check whether the items had the same meaning and reflected the construct of the initial document. After this analysis by the author of the GCQ and following her suggestions, the version was retranslated into Portuguese by the same translator who performed the synthesis in the previous stage.

\section{7th stage - Evaluation by experts and target population}

The last version of the GCQ in Portuguese was evaluated by two groups of judges, one consisting of seven professionals specialized in the theme where the instrument should evaluate (comfort, critical care, cardiology and psychometry), and the other consisting of 10 lay people who experienced infarction and ICU admission.

The experts evaluated the items proposed in the instrument in three stages. In the first stage, they evaluated every item in terms of relevance to comfort states, and in the second stage, they evaluated every item in terms of relevance to comfort contexts. In the first two stages, the evaluation was through a Likert scale, ranging from 1 (I do not agree) to 4 (I totally agree). In case of disagreement, they could suggest the inclusion, alteration or elimination of items. In the third stage, a semantic analysis was conducted, evaluating the language and clarity of the items for the target population. In this stage, the evaluation was also through a Likert scale, ranging from 1 (not clear) to 4 (very clear). If they considered the item not clear or little clear, they had a chance to present suggestions and alternative wording.

After the changes suggested by the first group of judges, the instrument was evaluated by the target population, that is, by the second group of judges, who checked it for comprehension and clarity of the items. This group consisted of 10 people diagnosed 
with infarction admitted to the ICU, who were contacted by the researcher after the first 24 hours in the ICU. They received explanations about the purpose of the evaluation, the ICF content and signature. In a conversation, each item of the GCQ-AMI was read, asking the patients about their understanding. Afterwards, the necessary adaptations were made, resulting in the preliminary version of the General Comfort Questionnaire (GCQ-AMI), which was submitted to a pre-test.

\section{8th stage - Pre-test}

This stage referred to the application of the instrument in an interview to identify interpretation issues. The GCQ-AMI instrument was applied to 30 patients with AMI in the ICU, who were contacted after 24 hours in the ICU, invited to participate in the study and who received guidance about the ICF and its signature. Each item was read once again, and the answer of the participant was recorded in the instrument, evaluating the adequacy of the instructions and scoring system adopted. The number of participants followed the criteria set in the literature, which define a sample of 30 to 40 people $^{(13)}$.

\section{9th stage - Evaluation of operational equivalence}

Finally, in the pre-test the operational equivalence was evaluated, which refers to the instrument application to the study population; it evaluates aspects such as: format of instrument items, type of paper and layout of visual elements of the instrument, and instructions to answer the items ${ }^{(8,10,14)}$.

\section{Data collection and organization}

A semi-structured interview was used for data collection, with the application of a sociodemographic questionnaire produced by the authors. In addition, the General Comfort Questionnaire for AMI was applied, which had 63 items presented on a Likert scale whose answers ranged from 1 (I totally disagree) to 4 (I totally agree). In this sense, the scale of measurement is increasing, that is, the greater the value attributed to the items, the greater the degree of comfort. The questions in the form were articulated with the states (calmness, relief and transcendence) and contexts (physical, environmental, socio-cultural and psycho-spiritual, presented in the comfort theory) ${ }^{(7)}$.

\section{Data analysis}

After the instrument evaluation by the experts, the suggestions for each item were analyzed and incorporated. To measure the proportion or percentage of judges who agreed on aspects of the instrument, the content validity index (CVI) was calculated by adding the scores of the items that received 3 or 4 divided by the total number of answers (seven judges). The CVI of 0.78 or above was considered adequate, as recommended by the authors for studies with six or more experts ${ }^{(9)}$. The items that had a CVI lower than 0.78 were reviewed. Data were stored and analyzed using SPSS for Windows 20.0.

\section{RESULTS}

\section{Conceptual equivalence}

After reviewing the literature about comfort, the relevance of the construct in the Brazilian context and its association with nursing theory and practice were analyzed ${ }^{(7,15)}$. In the course of the study of the theory underlying the GCQ, several emails were exchanged with Katherine Kolcaba, the instrument author, for a deep understanding of the instrument. The analysis of the national literature on the challenges, needs and experiences of people with AMI in the ICU showed that not all items of the GCQ considered these situations, thus requiring contextual adjustments. These elements, present in this condition of illness, were understood as related to the comfort construct, which originated 15 new items. Some of these challenges, needs and experiences are presented below, including the respective items that have been created to address them:

a) Fear of feeling pain again, excessive lighting, noise annoyance, social isolation, thirst sensation, restricted visiting time. These are: Item 52- You have chest pain now; Item 54- The lighting of this place bothers you; Item 63- You feel isolated; Item 49- You are thirsty; Item 57- You would like to spend more time with your family.

b) Discomfort caused by the use of equipment, difficulty to eliminate diuresis, feeling invisible as a person, having been hospitalized unexpectedly, feeling lost in time and space. These are: Item 62- The devices you use bother you; Item 55- You have trouble urinating; Item 51- The people who work here do not actually see you; Item 53- Your life has changed since you arrived here; Item 50- You do not know if it's now day or night;

c) Sleep interruption. Item 61- You have trouble sleeping;

d) Fear of death, uncertainty regarding recovery. Item 59 You do not know if you will recover; Item 56- You are afraid of dying;

e) Difficulty eating, difficulty breathing. Item 60 - It is hard to eat here; Item 58 - You are short of breath.

Based on the above, the GCQ-AMI was developed with 63 items.

\section{Semantic equivalence}

Translations T1 and T2 were evaluated in detail by the researchers to obtain the synthesis version. Fifteen items had extremely similar translations $(1,2,5,8,13,24,25,28,30,32,35,4$ $0,45,47)$, with variation basically related to the use of definite or indefinite article - the best option was chosen. Nineteen items of T2 $(3,4,9,10,12,14,15,17,19,23,27,31,38,39,42,46)$ and 13 items of T1 $(6,7,16,18,26,33,34,36,37,41,43,44,48)$ were selected, as they presented a better content understanding.

In addition, some words were replaced with synonyms to avoid unclear terms in the Brazilian culture. For example, in item 10, the verb used for "inspirar" and "lisonjear" was replaced with "valorizar." In item 11, "ambiente" was changed to its singular form, since in Brazil, the instrument is applied to one environment, that is, the ICU. In the synthesis of retranslations B1 and $\mathrm{B} 2$, the translator judged that 20 items of the B2 version $(1,4,8$ $, 10,12,15,16,22,26,27,30,35,39,41,46,47)$ and 9 items of the B1 version $(2,6,9,13,14,21,32,34,42)$ were more appropriate to create a synthesized version of the retranslations. The other items had a similar retranslation and were maintained $(3,5,7$, $17,20,23,25,28,29,31,33,40,43,45,48)$. 
The synthesis of the retranslations was sent to the author of the original document, who made the following suggestions: in item 2, replacement of "on my treatment" with "with my treatment"; in item 6, replacement of "lets" with "gets"; in item 12, replacement of "leave me relaxed" with "make me nervous"; in item 15, replacement of "happy" with "able"; in item 30, replacement of "make happy" with "is pleasant"; and in item 37 , replacement of "write" with "send".

These changes, recommended by the author of the original instrument, were considered relevant and incorporated into the new version. After this step, the instrument was again translated by the professional who performed the synthesis of the retranslations (B1 and B2).

After the retranslation, pronoun "meu" was replaced with "seu" in wording of the items, since the instrument was designed to be applied by the interviewer, and not through self-application, due to the low socioeconomic level of the patients of the public health services in Brazil.

The preliminary version of the GCQ-AMI was sent to experts for the evaluation of the relevance of the items to the state and context of comfort and for analysis of language and clarity of the items.

Regarding the analysis of the relevance of all 63 items to the state of comfort, 44 items $(69.4 \%)$ presented CVI of 1, 15 $(23.8 \%)$ of 85.7 , and $4(6.34 \%)$ of 71.1 . All 15 items added to the GCQ-AMI obtained scores higher than 0.78 in this evaluation.

In the analysis of the relevance of all 63 items to the context of comfort, 43 items (68.2\%) presented CVI of 1, $15(23.8 \%)$ of 85.7 , and 5 (7.9\%) of 79.3. All 15 items added to the GCQIAM also obtained scores higher than 0.78 in this evaluation.

The researchers decided to keep those few items that did not present a CVI of 0.78 or above in the analysis of the relevance to the state or context of comfort, considering that now a theoretical analysis of the instrument is conducted, which should be taken into account in the empirical phase of the GCQ-AMI validation, as indicated in Table 1.

As for the language and clarity of all 63 items, 26 items (41.2\%) presented CVI of 1, 28 (44.4\%) of 85.7, 9 (14.2\%) of 71.4. All suggestions from the judges were incorporated into the preliminary version of the GCQ-AMI, as indicated in Table 2.

In the evaluation of the items by the target population, the word "constipado" (Item 19) was understood by some patients as "have a cold". Then, it was replaced with "prisão de ventre".

In the last stage of the semantic evaluation, the GCQ-AMI pre-test was performed with 30 patients diagnosed with AMI hospitalized in the ICU. The mean response time of the instrument was 23 minutes. The instrument was well accepted by the group, no respondent considered it tiresome, despite its 63 items. All items were well understood, and the final version of the content analysis of the instrument was obtained, achieving operational equivalence. In addition, the instructions were considered clear and ended with the following phrase: "Thank you very much for helping us in this study about the concept of comfort. Some statements are presented below which may perhaps describe your state of comfort at the moment you answer these questions. For example: I am glad to answer this questionnaire about my comfort."

Table 1 - Specification of items of the General Comfort Questionnaire for patients with Acute Myocardial Infarction (GCQAMI) who presented a Content Validity Index (CVI) below 0.78 in the analysis by judges of the relevance to states and contexts of comfort, Salvador, Bahia, Brazil, 2016

\begin{tabular}{|c|c|c|c|c|}
\hline Item \# & Item & CVI & $\begin{array}{l}\text { State of the item } \\
\text { in the GCQ }\end{array}$ & $\begin{array}{l}\text { Opinion of judges about the } \\
\text { state of relevance of the item }\end{array}$ \\
\hline 3 & You have much privacy. & 0.71 & State of relief & State of calmness \\
\hline 11 & This place is pleasant. & 0.71 & State of calmness & State of transcendence \\
\hline 42 & This room has a bad smell. & 0.71 & State of calmness & State of relief \\
\hline 46 & You have found the meaning of life after you got sick. & 0.71 & State of relief & State of transcendence \\
\hline Item \# & Item & CVI & $\begin{array}{l}\text { Context of the item } \\
\text { in the GCQ }\end{array}$ & $\begin{array}{l}\text { Opinion of judges about the } \\
\text { context of relevance of the item }\end{array}$ \\
\hline 6 & Your health problem gets you down. & 0.43 & Sociocultural context & Psycho-spiritual context \\
\hline 10 & You feel loved by your family. & 0.71 & Sociocultural context & Psycho-spiritual context \\
\hline 32 & This bed hurts you. & 0.71 & Environmental context & Sociocultural context \\
\hline 35 & You feel out of place here. & 0.71 & Environmental context & Sociocultural context \\
\hline 51 & People who work here give attention to you. & 0.71 & Sociocultural context & Did not suggest \\
\hline
\end{tabular}

Note: General Comfort Questionnaire (GCQ); CVI: Content Validity Index 
Table 2 - Specification of items of the General Comfort Questionnaire for patients with Acute Myocardial Infarction (GCQAMI) who presented a Content Validity Index (CVI) below 0.78 in the analysis by judges of instrument language and clarity, Salvador, Bahia, Brazil, 2016

\begin{tabular}{cccc}
\hline Item \# & Item & CVI & Change suggested by the judges \\
\hline 4 & When you need help, you have someone to count on. & 0.57 & When you need help, you are supported by the professionals. \\
12 & Noise does not make you nervous. & 0.71 & Noise makes you nervous. \\
19 & You have constipation. & 0.71 & Constipation bothers you. \\
27 & The temperature is good in this room. & 0.71 & The temperature is good here. \\
35 & You feel out of place here. & 0.71 & You feel comfortable here. \\
40 & You feel out of control. & 0.71 & You feel you do not have control over the situation. \\
43 & You feel alone, but you do not feel lonely. & 0.71 & You feel alone here. \\
47 & It is easy to walk around here. & 0.71 & It is easy to walk in this area. \\
52 & The lighting of this place bothers you. & 0.71 & The brightness of this place bothers you. \\
\hline
\end{tabular}

\section{DISCUSSION}

During the the process of cross-cultural adaptation of the GCQ to people with myocardial infarction, in the evaluation of the conceptual equivalence of the comfort construct, the original instrument and its concepts presented relevance and applicability to the Brazilian context ${ }^{(8,16)}$.

In this stage, 15 items had to be added, since the original instrument did not widely consider the specificity of the experience of patients with infarction in the ICU. This fact could be expected since the QAQ was designed to evaluate the comfort of people in a general illness situation. These new items were validated in the semantic analysis by the two groups of judges (experts and target population), reinforcing the importance of literature exploration of empirical theories and studies, and analysis of researchers' own observation and experience regarding the specific condition of the target population. Then, the researchers ensured the items covered all aspects of the construct for the study population, since they were developed from the reports in the literature about the experience of this target population ${ }^{(13)}$. Items can be added after bibliographic review or with a focus group to explore the phenomenon according to cultural values and beliefs of the target population ${ }^{(8,17-18)}$.

All translations were performed as recommended in the literature, confirming the importance of following the recommendations according to the theoretical basis adopted to ensure the reliability of the semantic analysis ${ }^{(10-11)}$. Selecting the best translation in Portuguese is critical, so that the items do not present issues related to understanding or semantic and conceptual equivalence ${ }^{(18-19)}$. After the translations of the GCQ into Portuguese, the synthesis of the instrument translated in a single version by the authors was essential in this process, as they have experience in AMI patient care and could ensure the best understanding by the target population. In this stage, few changes were made.

The profile of the bilingual translators was equally important in the retranslation of the synthesized version from Portuguese into English, since their mother tongue was the instrument language and they had fluency in the language ${ }^{(8,10,20)}$. In addition, having the two English versions synthesized and translated by another professional who had not participated in the previous stages was very useful, as it kept the conceptual and semantic equivalence of the versions.

Also important was the evaluation of the GCQ-AMI by the author of the original document, since it allowed the analysis of words and expressions that did not reflect the conception of the original version. It is highly useful to have the author of the original instrument analyze the retranslated version to see if the items in their essence represent the same conceptual idea of the original items $\mathrm{s}^{(21)}$. In the retranslation of this version into Portuguese, a stronger alignment was observed between the instrument and the cultural context to which it was adapted.

The instrument analysis conducted by the group of judges was essential for the adaptation of the items of the original document to the Brazilian context. Guimaraes et al. ${ }^{(22)}$ suggest that, besides consolidated criteria for the selection of experts, such as degree, years after graduation, and field of work; clinical skills and experience should be considered preponderant factors for a successful evaluation process of the items, which can offer information for further suggestions and recommendations of instrument adjustments. The number of experts was sufficient for the GCQ-AMI content validation - the literature recommends at least three and no more than $20^{(13,23-25)}$.

It is important to note that the instructions provided to the judges for the GCQ-IAM evaluation were useful in the analysis of the relevance of the items to comfort states and contexts, and instrument understanding and language. The judges received information about the theory underlying the original document, the steps of the evaluation and what should be considered at each step. Then, the judges presented an informed opinion with clarity about the evaluation; they submitted the instruments properly filled out, which increased the quality of the information acquired in this stage.

In the perspective of the experts, no item of the original instrument had to be removed, only adjustments should be made to wording and content, including replacement of terms or phrases with others of better understanding or that were suitable to the target culture. According to Regnault and Herdman ${ }^{(10)}$, the removal of items may affect the measurement equivalence, since it may compromise the outcome of each item, with an impact on the psychometric 
evaluation of the instrument. Changes in wording of the items are expected in the process of cultural adaptation of instruments to maintain the semantic equivalence, with language accessible to the target culture, thus allowing a better comprehension ${ }^{(8,18)}$.

With the calculation of the Content Validity Index (CVI), related to the clarity and language of the items, only nine items of the instrument presented a value below 0.78 , which meant changes were required; in these cases, the suggestions of the judges were adopted. The literature confirms that a CVI below 0.78 requires changes in wording of the items for a better understanding by the target population ${ }^{(9,26)}$.

In the analysis of the relevance of the items to comfort states and contexts, only 4 and 5 items did not reach a CVI higher than 0.78 , respectively. In this stage of the adaptation process, the reallocation of the item in one or another state or context was not taken into account, because now a theoretical analysis of the instrument is performed, and these results should be considered in the empirical phase of the GCQ-AMI validation.

In the pre-test, whose objective was to evaluate the understanding and clarity of the instrument ${ }^{(27)}$ by the target population, only one item had to be replaced (constipação with prisão de ventre). Tthe GCQ-AMI was understood and easily answered by the target population, the instructions provided to participants were clear, obtaining the conceptual, semantic and operational equivalences of the instrument.

The final version of the instrument maintained the same format and sequence of the items as the original version and is ready to be submitted for empirical validity.

\section{Study limitation}

The study limitation refers to the application of the instrument in the pre-test to only 30 patients with myocardial infarction admitted to the ICU. The measurement equivalence is required to ensure greater study robustness.

\section{Contribution to Nursing}

The validation of this instrument enables to assess the level of comfort of patients with infarction through a multidimensional perspective, guiding nurses' actions that are focused on promoting comfort and fulfilling the needs of these individuals.

\section{FINAL CONSIDERATIONS}

This investigation reinforces the importance of conducting the stages of a cultural adaptation process, including a conceptual and item equivalence, development of a construct map, and a semantic equivalence comprising all stages recommended in the literature and the equivalence operational. These stages are relevant as they identify inaccuracies in the process that can lead to understanding issues related to the context to which the instrument is being adapted.

The GCQ-AMI presented the equivalences required in the process of cross-cultural adaptation; it has 63 items that should be answered using a Likert scale of 1 to 4 points. For an improved robustness of the study, it is essential to perform the measurement equivalence that is based on the investigation of the psychometric properties and reliability of the instrument.

The findings of this study indicate the Brazilian version of the General Comfort Questionnaire for AMI (GCQ-AMI) is a relevant instrument that presents evidence of content validity to evaluate the comfort of people with myocardial infarction admitted to the ICU. Studies on measurement equivalence will be conducted in the near future to complement this crosscultural validation process.

\section{REFERENCES}

1. Sociedade brasileira de cardiologia, hipertensão e nefrologia. VI Diretrizes Brasileiras de hipertensão arterial. Rev Bras Hipertens[Internet]. 2010[cited 2014 May 25];17(1):69-73. Available from: http://publicacoes.cardiol.br/2014/diretrizes/2016/05 HIPERTENSAO_ARTERIAL.pdf

2. Barth AA, Weigel BD, Drumer CD, Machado KC, Tisot TM. Estressores em familiares de pacientes internados na unidade de terapia intensiva. Rev Bras Ter Intens[Internet]. 2016[cited 2016 Nov 30];28(3):323-9. Available from: http://www.scielo.br/pdf/ rbti/v28n3/0103-507X-rbti-28-03-0323.pdf

3. Backes JC. Os paradoxos do trabalho em equipe em um Centro de Tratamento Intensivo Pediátrico (CTI-Pediátrico): explorando as articulações psicossociais no trabalho em saúde. Interface [Internet]. 2016[cited 2016 Dec 17];21(60):77-87. Available from: http://www.scielo.br/pdf/icse/v21n60/en_1807-5762-icse-1807-576220150875.pdf

4. Mussi FC, Koizumi MS, Ângelo M, Lima MS. Perda da espontaneidade da ação: o desconforto de homens que sofreram IAM. Rev Esc Enferm USP[Internet]. 2002[cited 2015 Nov 22];36(2):115-24. Available from: http://www.scielo.br/pdf/reeusp/v36n2/v36n2a02.pdf

5. Mussi FC, Freitas KS, Gibaut MAM. Prácticas del cuidar em enfermería: para la promotición del confort. Index Enferm[Internet]. 2014[cited 2015 Jun 30];23(1-2):65-9. Available from: http://dx.doi.org/104321/S1132-12962014000100014

6. Potti FS, Stahehoefer T, Felix JVC, Meier MJ. Medida de conforto e comunicação nas ações do cuidado de enfermagem ao paciente crítico. Rev Bras Enferm[Internet]. 2013[cited 2015 Apr 13];66(2):174-9. Available from: http://dx.doi .org/101590/ S0034-71672013000200004

7. Kolcaba K, DiMarco MA. Comfort theory and its application to pediatric nursing. Pediatric Nurs[Internet]. 2005 [cited 2014 May 21];31:3. Available from: https://www.ncbi.nlm.nih.gov/pubmed/16060582

8. Reicheinheim ME, Moraes CL. Operacionalização de adaptação transcultural de instrumentos de aferição usados em epidemiologia. Rev Saúde Pública[Internet]. 2007[cited 2013 Mar 4];41(4):665- 73. Available from: http://www.scielo.br/pdf/rsp/v41n4/en_6294.pdf 
9. Alexandre NMC, Colluci MZO. Adaptação cultural de instrumento que avalia atividades do trabalho e sua relação com sintomas osteomusculares. Acta Paul Enferm[Internet]. 2009[cited 2014 Sep 23];22(2):149-54. Available from: http://www.scielo.br/pdf/ ape/v22n2/a06v22n2.pdf

10. Regnault A, Herdman M. Using quantitative methods within the Universalist model framework to explore the cross-cultural equivalence of patient- reported outcome instruments. Qual Life Res[Internet]. 2015[cited 2016 Oct 27];24(1):115-24. Available from: http://dx.doi.org/10.1007/s111136-014-0722-8

11. Guillemin F, Bombardier C, Beaton D. Cross-cultural adaptation of health-related quality of life measures: literature review and proposed guidelines. J Clin Epidemiol[Internet]. 1993[cited 2013 Jun 20];46(12):1417-32. Available from: https://pdfs.semanticscholar. org/a2a8/fc3722ce868ac3cc37fd539f50afa31f4445.pdf

12. Góis JA. Adaptação transcultural e validade de conteúdo do questionário geral de conforto para pessoas com infarto do miocardio[Dissertação][Internet]. Salvador (BA): Escola de Enfermagem. Universidade Federal da Bahia; 2016 [cited 2016 Jun 21] Available from: http//repositorio.ufba.br/ri/handle/ri/20846

13. Alexandre NMC, Colluci MZO. Construção de instrumentos de medidas na área de saúde. Ciênc Saúde Colet[Internet]. 2013[cited May 2015 15];20(3):925-36. Available from: http://www.scielo.br/pdf/csc/v20n3/1413-8123-csc-20-03-00925.pdf

14. Gjesring L, Caplehom JRM, Clausen T. Cross cultural adaptation of research instruments: language, setting, time and statistical considerations. BMC Med Res Methodol[Internet]. 2010[cited 2011 Feb 14];10(13):1-10. Available from: https://bmcmedresmethodol. biomedcentral.com/articles/10.1186/1471-2288-10-13

15. Apostolo JLA, Kolcaba K, Martins MTCA, Mendes AMOC. Avaliação das qualidades psicométricas do conforto de doentes psiquiátricos. Psicológica. 2007;44:489-504.

16. Fattore GL, Teles CA, Santos DN. Validade de constructo da escala Experiences of Discriminations em uma população brasileira. Cad Saúde Pública[Internet]. 2016[cited 2016 Oct 22];32(4). Available from: http://www.scielo.br/pdf/csp/v32n4/1678-4464-csp32-04-e00102415.pdf

17. Nascimento MI, Monteiro GTR. Características de acesso ao preventivo de câncer de colo de útero: três etapas metodológicas e da adaptação do instrumento de coleta de informação. Cad Saúde Pública[Internet]. 2010[cited 2015 Nov 11];26(6):1096-108. Available from: http://www.scielo.br/pdf/csp/v26n6/04.pdf

18. Sampaio PF, Moraes CL, Reicheinheim ME. Equivalência conceitual, de itens, semântica e operacional da versão brasileira do EMBU para aferição das práticas educativas parentais em adolescentes. Cad Saúde Pública[Internet]. 2014[cited 2015 Jul 25];30(8):16338. Available from: http://www.scielo.br/pdf/csp/v30n8/0102-311X-csp-30-8-1633.pdf

19. Epstein J, Santo RM, Guillemin F. A review of guidelines for cross-cultural adaptation of questionnaires could not bring out a consensus. J Clin Epidemiol[Internet]. 2015[cited 2015 Dec 23];68:435-41. Available from: http://www.sciencedirect.com/science/ article/pii/S0895435614004995

20. Trotte LAC, Lima CFM, Pena TLN, Ferreira AMO, Caldas CP. Adaptação transcultural para o português do Endof Life Comfort Questionnarie Patient. Rev Enferm UERJ[Internet]. 2014[cited 2015 Jun 30];22(4);461-65. Available from: http://www.e-publicacoes. uerj.br/index.php/enfermagemuerj/article/view/13783/10525

21. Borsa JC, Damásio BF, Bandeira A. Adaptação de instrumentos psicológicos entre culturas: algumas considerações. Rev Paidéia[Internet]. 2012[cited 2015 Jan 15];22(33):423-32. Available from: http://www.e-publicacoes.uerj.br/index.php/enfermagemuerj/article/view/13783/10525

22. Guimarães HCQCP, Pena SB, Lopes JL, Lopes CT, Barros ALBL. Experts for validation studies in nursing: new proposal and selection criteria. Int J Nurs Knowl[Internet]. 2015[cited 2017 Dec 13];27(3):130-5. Available from: https://www.researchgate.net/ publication/277325061_Experts_for_Validation_Studies_in_Nursing_New_Proposal_and_Selection_Criteria

23. Polit DF, Beck CT. The Content Validity Index: are you sure you know what's being reported: critique and recommendations. Res Nurs Health[Internet]. 2006[cited 2015 Dec 15];29:489-97. Available from: http://onlinelibrary.wiley.com/doi/10.1002/nur.20147/abstract

24. Silva TOHN, Alves LBO, Balieiro MMFB, Mandetta MA, Tanner A, Shields L. Cross cultural adaptation of an instrument to measure the family centered-care. Acta Paul Enferm[Internet]. 2015[cited 2016 Jan 2];28(2):107-12. Available from: http://www.scielo.br/ pdf/ape/v28n2/en_1982-0194-ape-28-02-0107.pdf

25. Peduzzi M, Norman I, Coster S, Meireles E. Adaptação transcultural e validação da Reidness for Interprofissional Learning Scale no Brasil. Rev Esc Enferm USP[Internet]. 2015[cited 2016 Jan 10];49 (Esp2):7-15. Available from: http://www.scielo.br/pdf/reeusp/ v49nspe2/1980-220X-reeusp-49-spe2-0007.pdf

26. Soares MH, Luís MAV, Hirata AGP. Adaptação transcultural do Nursing Student Attitudes Toward Mental Health Nursing and Consumers no Brasil. Rev Bras Enferm[Internet]. 2015[cited 2016 Feb 9];68(2):198-205. Available from: http://www.scielo.br/pdf/ reben/v68n2/en_0034-7167-reben-68-02-0198.pdf

27. Oliveira WIF, Hernandez PJS, Souza KM, Piuvezan G, Gama ZAS. Equivalência semântica, conceitual e de itens do Observable Indicators of Nurse Home Care Quality Instrument. Ciênc Saúde Colet[Internet]. 2016[cited 2016 May 11];21(7):2243-56. Available from: http://www.scielo.br/pdf/csc/v21n7/1413-8123-csc-21-07-2243.pdf 